\title{
9. Realist Optimist: Coral Bell's Contribution to Australian Foreign and Defence Policy ${ }^{1}$
}

\author{
Brendan Taylor
}

In a collection of essays dedicated to the memory of TB Millar, Coral Bell described Millar as a scholar 'never given to provincialism: he was very much a citizen of the larger Western world, deeply fascinated by the problems of the East-West balance during the Cold War years'. ${ }^{2}$ This description is one that perhaps applies even more aptly to Coral and her work. Her preoccupation was very much the diplomatic and strategic relations between the great powers of what Coral liked to term 'the central balance'. Yet like Millar, a significant portion of her career was also spent advancing the study of Australian foreign and defence policy. As this chapter goes on to demonstrate, much of her work in this area addressed the interplay between the central balance and Australian policy. It did so by bringing a formidable grasp of history together with an enduring desire to decipher the contours of the emerging international political landscape. And despite her realist proclivities, Coral was also-by her own admission-very much the optimist regarding Australia's prospects in that emerging landscape.

\section{The Past as Prologue}

Coral's earliest experiences of Australian foreign and defence policy revolved much more around its practical elements than the academic study thereof. In a number of respects, she experienced the use of force against Australia in the most direct, even personal of ways. She spent three years (1942-1945) during the Second World War, for instance, in a University of Sydney physics laboratory which assisted with the degaussing of ships. In a short memoir of her career, she recalls purchasing a rather large poker for protection against any Japanese invasion. In characteristically colourful terms, she writes of her intent 'to sell my life or virtue as dearly as possible when they came up the garden path.'

\footnotetext{
1 A version of the essay has previously been published by Taylor \& Francis Ltd., as: Brendan Taylor, 'Coral Bell's contribution to Australian foreign policy', Australian Journal of International Affairs, vol. 59, no. 3, 2005, pp. 257-260; and has been reprinted by permission of the publisher.

2 Coral Bell, 'Preface', in Coral Bell, ed., Nation, Region and Context: Studies in Peace and War in Honour of Professor T.B. Millar, Canberra Papers on Strategy and Defence no. 112, 1995, Strategic and Defence Studies Centre, Canberra, 1995, p. xiii.
} 
Unduly dramatic as that may now seem in light of evidence that the threat of Japanese invasion was perhaps more imagined than real, ${ }^{3}$ Coral elsewhere does recall hearing 'a Japanese shell or two whistl[ing] overhead during the submarine raid of $1942 .{ }^{4}$ More tragically, she also lost her 'first love' during the Papua New Guinea campaign.

As the Second World War drew to a close, Coral decided to contribute to the practice of Australian foreign policy by entering the diplomatic service. She moved to Canberra in 1945 as one of ten new recruits - Coral being the only female among them. 'Doc' Evatt was the Minister for External Affairs at that time and Coral's new career brought her into contact with a number of historical figures of Australian foreign and defence policy, including the formidable Sir Arthur Tange. ${ }^{5}$

Her first assignment was under John Burton in the Department's United Nations Division. She moved subsequently to work on Southeast Asia, becoming the only desk officer in a small department - even by today's standards - to work on this entire sub-region. Coral was later dispatched to Wellington, New Zealand - a posting she regarded as a 'wooden spoon'. But it was a posting which saw her involved as a 'bit player' in negotiations leading up to the signing of the ANZUS (Australia New Zealand United States) agreement. Again in her memoir, Coral recounts a secret visit by then Head of the Department, Alan Watt, to talk the New Zealanders out of siding with Britain. When Watt arrived, the High Commissioner and Official Secretary were elsewhere, leaving Coral as the only staffer 'holding the fort.'

Notwithstanding her involvement in the practice of Australian foreign policy during such a formative period, Coral never made any secret of the fact that she disliked diplomatic life and felt immeasurably more comfortable in the corridors of academia. She was never attracted to the prospect of being a mere 'cog in the wheel' of government. At a more personal level, the more debauched side of diplomatic life was anathema to Coral's character. As she recalls:

[T] he diplomatic life-style did not really suit me. I have never been, in any of its senses, a party girl, and diplomacy is a very party-ridden occupation, especially in a small post, as Wellington then was. If you meet roughly the same fifty or so people at cocktail and dinner parties five evenings a week, you tend to run out of small talk, which has never been my favourite form of conversation anyway. I needed a more reflective kind of life.

\footnotetext{
3 For further reading see Peter Dean, ed., Australia 1942: In the Shadow of War, Cambridge University Press, Port Melbourne, 2013.

4 Coral Bell, 'Australians and Strategic Inquiry', in Bell, Nation, Region and Context, p. 51.

5 For further reading see Peter Edwards, Arthur Tange: Last of the Mandarins, Allen \& Unwin, Sydney, 2006.
} 


\section{Living with Giants}

After six years in the diplomatic service, Coral left Australia and spent most of the next two and a half decades in the United Kingdom, where she first went to take up graduate study at the London School of Economics (LSE). Here she encountered the renowned International Relations theorist Martin Wightwho Coral identified as 'the chief intellectual influence of my entire life' and frequently described in conversation as her 'guru.' During this period she also worked as a research officer at the Royal Institute of International Affairs (Chatham House), where the renowned historian Arnold J Toynbee handed her the editorial reins to Survey of International Affairs - a flagship Chatham House publication and almost certainly the most authoritative textbook in international politics at that time.

Coral went on to take up an appointment at the University of Manchester. In 1959 she also held a Rockefeller Fellowship in the US, which allowed her to spend time as a visiting academic at Columbia University and the School of Advanced International Studies in Washington. Over the course of this entire period, Coral came into contact with key figures in the fields of strategic studies and international relations, including the likes of Alastair Buchan, Hedley Bull, Michael Howard and Henry Kissinger.

These encounters were significant from an Australian perspective in that they raised the intellectual profile of analysis from this country. Denis Healey, the former British Labor MP and one of the founding fathers of the International Institute for Strategic Studies (IISS), observed in his own memoir that 'from the middle fifties Australia has contributed far more to international understanding of defence problems than any country of similar size. ${ }^{6}$ Certainly he had Coral in mind when making this observation. Secretary of the Department of Foreign Affairs, Sir Keith Waller, made a similar observation of Coral in the early 1970s when he wrote that 'her work has brought a new lustre to the reputation of Australia in all countries where people follow the serious study of foreign affairs. ${ }^{7}$

Coral herself was never shy about referring to her antipodean origins and offering a distinctly Australian perspective on international politics. In her classic 1968 Adelphi paper on the Asian balance of power, for instance, she stated from the outset that:

6 Denis Healey, The Time of My Life, Michael Joseph, London, 1989, p. 192.

7 Cited in Coral Bell, Crises and Australian Diplomacy, Arthur F Yencken Memorial Lecture 1972, Australian National University Press, 1973, p. 1. 
It will be an Australian view in the sense that the author, as an Australian, must be conscious that her own country's efforts to provide for its future security should include some assessment of the prospects for such a balance. Perhaps there is a certain appropriateness to an Australian examination of this question, since Australians are the only group of Westerners who must remain fully and inescapably vulnerable to the diplomatic stresses arising in Asia, on whose periphery they live or die. ${ }^{8}$

By the 1960s, however, Coral was beginning to feel the pull of home, a feeling exacerbated by the unexpected passing of her father (Coral's mother had also passed away unexpectedly, of a brain aneurism, when Coral was a child). She thus returned to Australia for four years during the early 1960s as the University of Sydney's first appointment in the field of international relations. Here she first encountered a young Desmond Ball, another emerging Australian scholar of strategic studies who, like Coral, would go on to make a significant impact internationally. ${ }^{9}$

Yet for a scholar really beginning to make her mark on the international scene, one gets the sense that Australia was simply too small and too remote for Coral at that time. In her memoir she recalls that 'Australia seemed suddenly to be in a lonely place, internationally, diplomatically and strategically'. To be sure, amongst her students at Sydney there were some who would make their own mark internationally, such as Richard Butler and Martin Indyk. Owen Harries, who would go on to become editor of the prominent American policy journal, The National Interest, was also a colleague and 'cherished friend.' Yet Coral 'did not find the intellectual climate of Australia in the late Menzies period much to my liking.' Hence, when the offer of a Readership at LSE came along, Coral 'was not much tempted to resist it'.

Coral retained some interest in Australian foreign and defence policy during her time away. In 1972, for instance, she delivered the Arthur F Yencken Memorial Lecture on the theme of 'Crises and Australian Diplomacy.' She divided the lecture into two parts, delivered over two evenings. The first addressed the nature of crises more generally and how they are managed by the great powers. The second examined their impact upon Australia and what, if anything, Australian diplomacy might do to ameliorate or influence them. ${ }^{10}$

When Coral returned permanently to Australia in the late 1970s - to take up a position as Senior Research Fellow in the Department of International Relations

8 Coral Bell, The Asian Balance of Power: A Comparison with European Precedents, Adelphi Paper no. 44, International Institute for Strategic Studies, London, February 1968, p. 1.

9 For further reading on the life and work of Ball see Brendan Taylor, Nicholas Farrelly and Sheryn Lee (eds), Insurgent Intellectual: Essays in Honour of Professor Desmond Ball, Institute of Southeast Asian Studies, Singapore, 2012.

10 Coral Bell, Crises and Australian Diplomacy. 
at The Australian National University (ANU) — this interplay between the global and Australian policy remained a theme of her research. For instance, in 1980 she edited a volume considering choices in Australian foreign and defence policy, including a chapter which Coral contributed entitled 'The Central Balance and Australian Policy.' As she wrote in that chapter, 'Australia's security has always, one may argue, been taken by its decision-makers to depend on its status as a protégé of one of the central-balance powers' ${ }^{11}$

This latter observation was a central element of what is almost certainly Coral's most significant contribution to the study of Australian foreign and defence policy. Dependent Ally was first published in 1984 and went on to appear in at least three different editions. It examined the evolution of Australia's relations with Britain and the United States over the previous two hundred years. It did so with an eye to illustrating some of the dilemmas of diplomatic and strategic dependency, as well as some of the costs and benefits of alliance.

One of the most enduring conclusions to emerge from Coral's sweeping study was the manner in which Australia's dependency on its great and powerful friends has not remained entirely consistent but has instead been subject to a variety of influences. Foremost amongst these, Dependent Ally concluded, was the personality and assumptions of Australia's chief decision-maker at any given time. As Coral so colourfully put it:

One might see the history as that of a succession of chefs with the same basic raw material to work on, and much the same 'notional preferences' among the consumers. The flavour and texture and palatability of what is achieved will vary chiefly in accordance with their respective skills and techniques, because there are not many other factors of variation. ${ }^{12}$

A standout feature of Dependent Ally is Coral's deep knowledge and application of history which is, indeed, a feature of much of her work. In surveying the history of the British-Australian relationship, for instance, she reaches back to the 1850s to an episode during the Crimean War which she argues highlights some of the central problems of the relationship which would culminate with Australia's 'turn to America' almost a century later. ${ }^{13}$ Later in the book she again draws comparisons between the time at which she was writing and the world a hundred years previous: 'the diplomatic wheel seems to have turned full circle

11 'The Central Balance and Australian Policy', in Coral Bell (ed), Agenda for the Eighties, Australian National University Press, Canberra, 1980, p. 6. A decade on, Coral edited a second such volume which included a similarly titled contribution. See Coral Bell, 'The Changing Central Balance and Australian Policy', in Coral Bell (ed), Agenda for the Nineties: Australian Choices in Foreign and Defence Policy, Longman Cheshire, Melbourne, 1991, pp. 1-23.

12 Coral Bell, Dependent Ally: A Study in Australian Foreign Policy, Allen \& Unwin, Sydney, 1984, p. 175.

13 ibid., p. 7. 
over a century, Russia being a Pacific power in the 1990s as it had been in the 1890s. Then it was a putative adversary, to be succeeded by quite an assortment of other actual or putative adversaries' ${ }^{14}$

Like so many scholars of international relations and strategic studies, Coral spent the early years of the 1990s adjusting to and trying to make sense of the collapse of the Soviet Union and the ending of the Cold War. In 1991 for instance, she produced a short monograph examining Australia's alliance options in a world transformed. The potential significance of these shifts was captured by Coral's observation that they represented 'nothing less than the disappearance of the whole organizing principle of the world in which ANZUS was created'.${ }^{15}$ Notwithstanding these epochal changes, Coral remained convinced that Australia's alliance with the United States would endure over the short to medium term. This was in large part due to her pessimism that a still nascent Asian regionalism could deliver a satisfactory alternative. Over the longer term, she presciently observed, the 'central balance' was likely to evolve in ways not necessarily as conducive to Australia as had been the case previously. Against that backdrop, Coral posited that the expectation of strong backing from its American ally-particularly during a crisis-would remain critically importantly to Canberra. ${ }^{16}$

Next only to Dependent Ally, however, Coral's most substantial contribution in the field of Australian foreign policy came in the form of her 2005 Australian Strategic Policy Institute (ASPI) paper Living with Giants. ${ }^{17}$ In this study, Coral peered several decades into the future in an attempt to decipher the shape of the emerging landscape of international politics. Her focus was primarily upon the security implications of population growth and, in the main, the fact that the world several decades from now will be comprised of at least nineteen societies of at least a hundred million people. Of particular significance to Australia, ten of these would be located within Australia's own area of primary strategic concern.

Despite the potential for a re-run of the 1930s conflict between the 'haves' and the 'have nots' - albeit on a much larger scale - Coral saw at least two positive diplomatic patterns emerging as part of this new landscape. The first was the beginnings of a 'regional security community' built around the fledging ASEAN-plus-three countries, as well as Australia and New Zealand. Second, she also suggested that the US-led unipolar world was fast reaching its twilight and

14 ibid., p. 185.

15 Coral Bell, Australia's Alliance Options: Prospect and Retrospect in a World of Change, Australian Foreign Policy Publications Program, The Australian National University, Canberra, 1991, p. 2.

16 ibid, p. 57.

17 Coral Bell, Living with Giants: Finding Australia's place in a more complex world, Strategy Report, Australian Strategic Policy Institute, Canberra, April 2005. 
that it could be replaced by a global 'concert of powers' - a concept discussed at greater length by Hugh White in his contribution to this volume-comprising at least eight nuclear powers and possibly other countries. Coral saw such a structure as a far safer alternative than a competitive 'balance of power' between these 'giants.'

Coral's exploration of the emerging landscape of international politics and its relevance to Australia continued in her 2007 paper The End of the Vasco da Gama Era, which was published under the auspices of the Lowy Institute for International Policy. ${ }^{18}$ In this study, Coral identified four powerful historical factors that were shaping this landscape. First, the end of the Vasco da Gama era - a term she used to refer to the end of the five hundred years of Western ascendency over Asia. Second, she again pointed to the end of the 'unipolar moment.' Third, a changing distribution of power both between and within states. And finally, environmental change.

Of these four forces, Coral saw the end of the Vasco da Gama era and environmental change as having the most significant ramifications for Australia. But she was also optimistic regarding the prospects for order in the emerging multipolar structure, namely because the greatest challenges to that order- the 'Jihadists', climate change and the proliferation of nuclear weapons to small powers - were all emerging outside the circle of the six most obvious great powers of the new order - the US, the European Union (EU), China, India, Russia and Japan. This, Coral argued, was likely to facilitate cooperation amongst the six with respect to these challenges.

Throughout her long and distinguished career, optimism remained a consistent feature of Coral's work. And it certainly rings through strongly in the conclusion to The End of the Vasco da Gama Era:

But there is no reason for Canberra to view with apprehension the coming of a prospective multipolar world balance. We have no special enemy among the six great powers who appear likely to share the governance of that emerging world. ... As middle powers go, Australia is exceptionally well endowed with both economic and strategic assets. ... The United States will remain the paramount power in the society of states, only in a multipolar world instead of a unipolar or bipolar one. ${ }^{19}$

Yet this sense of optimism should not be mistaken for complacency. Rather, Living with Giants and The End of the Vasco da Gama Era both illustrate the extent to which Coral was consistently pushing the envelope in an unrelenting

18 Coral Bell, The End of the Vasco da Gama Era: The Next Landscape of World Politics, Lowy Institute Paper

21, Lowy Institute for International Policy, Sydney, 2007.

19 ibid, pp. 52-53. 
drive to look imaginatively toward the future. This is certainly made clear in the conclusion to Living with Giants, which contains echoes of Barbara Tuchman's influential history of the opening days of the First World War, The Guns of August, and its central argument that miscalculation and a failure of imagination sent the European powers tumbling into the abyss of war. ${ }^{20}$ In Coral's terms:

This essay was inspired by the conclusion of the September 11 Commission report, naming a 'failure of imagination' as the origin of the disaster. Its speculations have been intended to promote the avoidance of a similar danger for Australia. ${ }^{21}$

\section{Influencing the Climate of Opinion}

Coral's contributions to Australian foreign and defence policy clearly extends beyond the scholarly works referred to in this chapter. To be sure, her impact has not been as direct as some of her long-standing academic colleagues, such as Paul Dibb whose 1986 Review of Australia's Defence Capabilities has had such a profound influence on the shape of Australian strategic policy during the period since, ${ }^{22}$ or Desmond Ball, whose path-breaking work on US strategic installations in Australia markedly expanded the contours of the public debate on this subject. ${ }^{23}$

It could be argued, however, that Coral was more a believer in the power of analysis to filter its way indirectly into the system. As she once observed, 'it is of course always difficult to show direct causal connection between the choices of decision-makers and the analyses published by outsiders, but such analyses do help create the climate of opinion within which both the policy makers and the decision makers live, work, and have their being. ${ }^{24}$

During her career, Coral influenced that climate of opinion in a number of ways. Internationally, she did so (and lifted Australia's diplomatic profile in the process) through her conversations with prominent statesmen - such as Henry Kissinger, who has cited her prominently in his own work ${ }^{25}$ - and through her appearance in a number of high-profile American policy journals, such as Foreign Affairs, The National Interest, and The American Interest. ${ }^{26}$

20 Barbara Tuchman, The Guns of August, MacMillan, New York, 1962.

21 Bell, Living with Giants, p. 55.

22 Report to the Minister for Defence by Mr Paul Dibb, Review of Australia's Defence Capabilities, Australian Government Printing Service, Canberra, 1986.

23 See, for example, Desmond Ball, A Suitable Piece of Real Estate: American Installations in Australia, Hale and Iremonger, Sydney, 1980.

24 Bell, 'Australians and Strategic Inquiry', p. 70.

25 See, for example, Henry Kissinger, Does America Need a Foreign Policy?, 2nd edn, Touchstone, New York, 2002 , p. 288.

26 See, for example, Coral Bell, 'The Twilight of the Unipolar World', The American Interest, vol. 1, no. 2, Winter 2005, pp. 18-29. 
Coral also influenced that climate of opinion through the people she worked with, taught and mentored. Former students recall with fondness the seminars and now almost legendary morning teas which were held during the 1970s and 1980s at the ANU HC Coombs building. Through her presence and participation in these, Coral contributed in a substantial way to the education of a significant number of emerging scholars. Many of those subsequently moved on to take up senior positions in academia, government and the military.

Moreover, during a period when women were woefully under-represented in the Australian foreign and defence policy debate, it is worth keeping in mind that Coral served for over half a century-ever since her appointment as one of Australia's first female diplomats - as a mentor and role model for female scholars and practitioners working in these fields. In March 2005 for instance, she was the keynote speaker at the inaugural meeting of the Canberra chapter of the 'Women in International Security' initiative.

\section{From the Shadows}

Despite her passing, Coral's work continues to exhibit particular relevance to a number of Australia's contemporary foreign and security policy debates. There has been recent speculation, for instance, that Washington is becoming increasingly frustrated by Canberra's unwillingness to assume a greater share of the defence burden at a time when the US is hurting financially. These tensions were apparent in the lead up to the 2012 AUSMIN talks, for instance, when Pacific Commander Admiral Samuel Locklear and Assistant Secretary of State Kurt Campbell each expressed concerns about the Australian defence budget. ${ }^{27}$ Speaking with an Australian Financial Review journalist in August 2013, former Deputy Secretary of State Richard Armitage was even more direct, arguing that Australia simply cannot continue 'free-riding' on its alliance with America. ${ }^{28}$

While these are indeed valid criticisms that should not be taken lightly, Coral's work reminds us that they are not particularly new ones. In Dependent Ally, for instance, she makes the following observation regarding the pattern of commitment of Australian forces in support of allied operations and the levels of funding budgeted for defence:

The forces sent were as near to 'token' size as the ally concerned could be induced to acquiesce in. Australian defence policy-makers seem to

27 See Peter Jennings, 'Trunk Call for AUSMIN', The Strategist, Australian Strategic Policy Institute, 12 November 2012.

28 Christopher Joye, 'Free Ride on US Defence Must Stop', Australian Financial Review, 19 August 2013. 
have been as passive, politically, as any liberal could wish, not activist or adroit, even about getting what they would regard as funds adequate to the sort of armoury Australia needed. ${ }^{29}$

Coral's work is also of continuing relevance to what is arguably Australia's leading foreign and defence policy debate of recent years regarding this country's response to the rise of China. A central figure in this debate, Hugh White, has written extensively on the dilemmas he believes Australia faces given that its leading economic and strategic partners - China and the US - are on opposite sides of a deepening strategic competition. He sees the possibility looming - potentially sooner than many analysts may believe-of Canberra having to choose between the US and China in the context, for instance, of an armed clash between China and Japan over the disputed Senkaku/Diaoyu Islands. ${ }^{30}$ However, by observing that there has traditionally been a 'slow motion quality' to Australia's responses to changed strategic circumstances, Coral reminds us that White's 'China choice' is quite unlikely to play out in the manner he describes, if indeed there is even a choice of that nature to be made at this present juncture in history. ${ }^{31}$

Indeed, rather than a stark choice occasioned by deepening strategic rivalry between the US and China, the next two to three decades is much more likely to involve a mix of cooperation and competition between these two heavyweights. Contemporary analytical frameworks for understanding the US-China relationship have thus far proven unable to anticipate and to accommodate these dynamics particularly well. Instead, they have tended to gravitate towards one of two opposing poles. At one end of the spectrum, pessimists such as John Mearsheimer and Aaron Friedberg point to the inevitability of strategic competition between the US and China. ${ }^{32}$ At the other, optimists such as Henry Kissinger, Zbigniew Brzezinski and White himself have instead pointed to the possibility of a power-sharing agreement between Beijing and Washington. This idea reached the peak of its popularity during the 2008-2009 global financial crisis in the form of calls for a ' $\mathrm{G} 2$ '. ${ }^{33}$

Developed during the 1960s, Coral's concept of a 'shadow condominium' offers a 'third way' between these two diametrically opposing positions and one that is potentially better able to capture to competitive and cooperative dynamics of

\footnotetext{
29 Bell, Dependent Ally, p. 176.

30 See, for example, Hugh White, 'Australia's Choice: Will the Land Down Under Pick the United States or China?', Foreign Affairs, 4 September 2013.

31 See Bell, Dependent Ally, p. 178.

32 See, for example, John J Mearsheimer, The Tragedy of Great Power Politics, WW Norton \& Company, New York, 2001; and Aaron L. Friedberg, A Contest for Supremacy: China, America, and the Struggle for Mastery in Asia, W.W. Norton and Company, New York, 2011.

33 See, for example, Zbigniew Brzezinski, 'The Group of Two That Could Change the World', Financial Times, 14 July 2009.
} 
the emerging US-China relationship. ${ }^{34}$ Inspired by the dynamics of superpower diplomacy during the Cuban Missile Crisis (which marked its fiftieth anniversary in the same year as Coral's passing), the 'shadow condominium' that she referred to was a temporary power-sharing arrangement that emerged during periods of acute crisis engaging the interests of the two dominant powers. But once the danger had passed, this arrangement retreated 'into the shadows of the future' and default adversarial postures resumed.

Ever the optimist - albeit one with strong realist proclivities - Coral maintained that there was always a prospect for the condominium to re-emerge out of those shadows during times of deep crisis. In her view, periods of power transition are especially conducive to such arrangements because they are invariably dangerous and difficult. The primary function of the 'shadow condominium' during such periods is to provide stability through joint great power management of the balance of power.

In the context of Asia's current power shift, the best evidence that Bell's 1960s template applies aptly to US-China relations comes from the Korean Peninsula. To be sure, strategic competition between China and the US has been a perennial feature of security politics surrounding this flashpoint. ${ }^{35}$ Arguably of greater interest, however, has been the cooperation that has occurred between Beijing and Washington during periods of crisis.

In early 2003, following the collapse of the 1994 Agreed Framework, for instance, Beijing and Washington worked to initiate three party talks with North Korea which subsequently morphed into a larger and moderately successful Six Party format. Again in 2006, in the midst of heightened tensions following North Korea's first nuclear test, American and Chinese officials came together to bring North Korea back to the negotiating table. ${ }^{36}$ In 2010, following the North's November bombardment of Yeonpyeong Island, tensions heightened to the point where highly respected analysts such as Victor Cha pointed to the possibility of all out conflict between the two Koreas. ${ }^{37}$ By December, however, Beijing and Washington were again reportedly working together to create calm. ${ }^{38}$

This pattern recurred once more following the sudden death of North Korean leader Kim Jong-Il in late 2011. The US and China maintained very close contact

\footnotetext{
34 Coral's concept of a 'shadow condominium' is outlined in Coral Bell, The Debatable Alliance: An Essay in Anglo-American Relations, Chatham House Essays No.3, Oxford University Press, London, 1964, pp. 108-113.

35 See Benjamin Schreer and Brendan Taylor, 'The Korean Crises and Sino-American Rivalry', Survival, vol. 53, no. 1, February-March 2011, pp. 13-19.

36 For a useful summary of US-China cooperation during this period see Bonnie S Glaser and Wang Liang, 'North Korea: The Beginning of a China-US Partnership', The Washington Quarterly, vol. 31, no. 1, Summer 2008, pp. 165-180.

37 Victor Cha, 'What to do about N. Korean Aggression?', The Chosun Ilbo (English edition), 6 December 2010.

38 See Mark Landler, 'China's North Korea Shift Helps US Relations', New York Times, 23 December 2010.
} 
in the aftermath of that event. Indeed, during a visit to Beijing at the time, Assistant Secretary of State Kurt Campbell spoke in terms not inconsistent with Coral's 'shadow condominium' concept when intimating that 'I think the US and China share a strong determination to maintain peace and stability'.$^{39}$

Will a US-China 'shadow condominium' manifest itself in the case of future strategic crises - in the South China Sea, the East China Sea, or over Taiwan - if and when these emerge? Only time will tell. Yet aside from the fact that it was conceived by one of our great strategic intellectuals, Australian foreign and defence policy-makers might do well in the meantime to entertain and further explore the possibility.

First, it offers a more realistic way of thinking about US-China relations than a more formal, institutionalised power-sharing arrangement, such as the 'G2'. Beijing and Washington simply do not share the same common values or compatible strategic cultures necessary to sustain an arrangement of that nature. ${ }^{40}$ Second, a US-China 'shadow condominium' will be more palatable to countriesincluding Japan and India - who fear their potential marginalisation under a more formal US-China power-sharing arrangement because they read it as a step towards some mild form of world government. Finally, and most importantly, a US-China 'shadow condominium' is also a more attractive proposition than the intense and inherently unstable US-China strategic competition that some analysts predict, along with the stark strategic choices that such competition would likely imply for Australia.

39 US Department of State, Kurt M. Campbell, Assistant Secretary, Bureau of East Asian and Pacific Affairs, 'Remarks to the Media on Departure at the Beijing Capital Airport', 4 January 2012.

40 For a useful critique of the 'G2' concept see Elizabeth C Economy and Adam Segal, 'The G2 Mirage: Why the United States and China are Not Ready to Upgrade Ties', Foreign Affairs, vol. 88, no. 3, May/June 2009, pp.14-23. 
This text taken from Power and International Relations:

Essays in honour of Coral Bell, edited by Desmond Ball and Sheryn Lee, published 2014 by ANU Press, The Australian National University, Canberra, Australia. 